\title{
KARNOPRAWNA OCHRONA OBIEKTÓW I TERENÓW CHRONIONYCH W ŚWIETLE WYBRANYCH PRZEPISÓW ROZDZIAŁU XXII KODEKSU KARNEGO (ART. 181 § 2 I 5, ART. 187, ART. 188 K.K.)
}

Celem prawnokarnej ochrony środowiska jest przede wszystkim utrzymanie równowagi przyrodniczej oraz dążenie do zachowania możliwości odnawiania zasobów naturalnych ${ }^{1}$. Polski Kodeks karny (dalej: K.k.) zawiera pięć samoistnych typów przestępstw (dwa stanowią odmianę nieumyślną ${ }^{2}$, do znamion których należy szczególne miejsce ich popełnienia w postaci „terenu lub obiektu objętego ochroną". Mieszczą się one w rozdziale przestępstw przeciwko środowisku. Realizują tzw. tradycyjną ochronę przyrody o tzw. charakterze konserwatorskim ${ }^{3}$. Są to przestępstwa stypizowane w art. 181 § 2 i 5, art. 187 oraz art. 188 K.k. Przepisy te mają charakter akcesoryjny ; przy ich wykładni konieczne jest odwołanie się do innych niż Kodeks karny ustaw, przede wszystkim ustawy z dnia 27 kwietnia 2001 r. - Prawo ochrony środowiska ${ }^{5}$ oraz ustawy z dnia 16 kwietnia 2004 r. o ochronie przyrody ${ }^{6}$. Przepisy art. 181 i art. 187 K.k. są o tyle interesujące, że, w odróżnieniu od większości przestępstw stypizowanych w tym rozdziale, nie mają charakteru

\footnotetext{
* Dr hab., Uniwersytet Marii Curie-Skłodowskiej; e-mail: magdalena.budyn-kulik@ poczta.umcs.lublin.pl, https:/ / orcid.org/0000-0002-3258-9855.

1 D. Gruszecka, Przestępstwa przeciwko środowisku, w: Kodeks karny. Komentarz. Część szczególna, red. J. Giezek, Warszawa 2014, s. 400.

2 Odmiennie J. Lachowski, który traktuje typy nieumyślne jako uprzywilejowane. J. Lachowski, Przestępstwa przeciwko środowisku, w: Kodeks karny. Komentarz, red. V. Konarska-Wrzosek, Warszawa 2016, s. 841, 852.

3 D. Gruszecka, Przestępstwa przeciwko środowisku, s. 400.

4 Tamże.

5 Tekst jednolity: Dz. U. z 2020 r. poz. 1219 z późn. zm.

6 Tekst jednolity: Dz. U. z 2020 r. poz. 55 z późn. zm.
} 
formalnego i nie są przestępstwami z abstrakcyjnego narażenia na niebezpieczeństwo ${ }^{7}$.

\section{Rodzajowy przedmiot ochrony}

Rodzajowym przedmiotem ochrony wszystkich omawianych czynów zabronionych jest środowisko ${ }^{8}$. Jest to dobro uniwersalne, przyczyny ochrony którego są dwojakiego rodzaju: samoistne oraz pośrednie - utrzymanie środowiska w stanie niepogorszonym wpływa na zakres ochrony takich dóbr indywidualnych, jak np. życie i zdrowie ${ }^{9}$. Środowisko obejmuje biosferę, przyrodę rozumianą jako ogół organizmów żywych, a także inne jej elementy ${ }^{10}$. Pojęcie to zostało zdefiniowane w przepisie art. 3 pkt 39 ustawy Prawo ochrony środowiska jako ogół elementów przyrodniczych, w tym także przekształconych w wyniku działalności człowieka, a w szczególności powierzchnię ziemi, kopaliny, wody, powietrze, zwierzęta i rośliny, krajobraz, klimat oraz pozostałe elementy różnorodności biologicznej, jak również wzajemne oddziaływania pomiędzy tymi elementami. Definicja środowiska przyrodniczego znajduje się w art. 5 pkt 20 ustawy o ochronie przyrody. W myśl tego przepisu jest to krajobraz wraz z tworami przyrody nieożywionej oraz naturalnymi i przekształconymi siedliskami przyrodniczymi z występującymi na nich roślinami, zwierzętami i grzybami. Pojęcia te nie są tożsame zakresowo; pojęcie środowiska przyrodniczego jest węższe niż środowiska, niewątpliwie się w nim zawiera. Wydaje się, że elementem, który mieści się $\mathrm{w}$ pojęciu środowiska, ale nie $\mathrm{w}$ pojęciu środowiska przyrodniczego, jest klimat. Powstaje wątpliwość, czy przedmiotem ochrony w omawianych przepisach jest środowisko w ogóle, czy środowisko przyrodnicze. Ze względu na brzmienie tytułu rozdziału Kodeksu

7 D. Gruszecka, Przestępstwa przeciwko środowisku, s. 401.

8 M. Kulik, Przestępstwa przeciwko środowisku, w: Kodeks karny. Komentarz, red. M. Mozgawa, Warszawa 2015, s. 483; J. Sobczak, Przestęstwa przeciwko środowisku, w: Kodeks karny. Komentarz, red. R.A. Stefański, Warszawa 2015, s. 1027; M. Gałązka, Przestępstwa przeciwko środowisku, w: Kodeks karny. Komentarz, red. A. Grześkowiak, K. Wiak, Warszawa 2015, s. 920; G. Bogdan, Przestęstwa przeciwko środowisku, w: Kodeks karny. Komentarz. Część szczególna, t. 2, red. A. Zoll, Warszawa 2008, s. 549.

9 Por. szerzej D. Gruszecka, Przestępstwa przeciwko środowisku, s. 402.

10 Tamże, s. 401. 
karnego, w którym znajdują się te przepisy, właściwszym źródłem wydaje się być ustawa Prawo ochrony środowiska. Samo brzmienie przepisów zebranych $\mathrm{w}$ rozdziale XXII sugeruje raczej ochronę środowiska przyrodniczego. Nie ma chyba jednak przeszkód, skoro ustawodawca w Kodeksie karnym używa określenia ogólnego „środowisko”, aby przyjąć, że przedmiotem ochrony czynów zabronionych zgromadzonych $w$ tym rozdziale jest środowisko w rozumieniu ustawy Prawo ochrony środowiska. Na marginesie należy zauważyć, że nie jest dobrze, gdy ustawodawca w różnych aktach prawnych regulujących podobne kwestie inaczej definiuje pokrewne pojęcia, nie określając ich wzajemnej relacji.

\section{Czyn zabroniony $\mathrm{z}$ art. 181 § 2 K.k.}

W komentarzach do art. 181 § 2 K.k. rzadko pojawiają się rozważania odnoszące się do indywidualnego przedmiotu ochrony. Zwykle dotyczą one przestępstwa z $\S 1$. W omawianym przypadku za indywidualny przedmiot ochrony należy uznać właśnie niezakłócone funkcjonowanie ekosystemu na terenie objętym ochroną. Niektórzy autorzy wskazują jako indywidualny przedmiot ochrony integralność roślin lub zwierzą ${ }^{11}$; rośliny i zwierzęta na terenie objętym ochroną ${ }^{12}$.

Czynność wykonawcza przestępstwa z art. 181 § 2 K.k. polega na niszczeniu lub uszkadzaniu. Czynu można się dopuścić zarówno przez działanie, jak i przez zaniechanie ${ }^{13}$. Typowo czyn popełniany bywa głównie przez działanie, np. zerwanie rośliny, podeptanie rośliny, ale może polegać również na zaniechaniu, np. gdy sprawca nie powstrzymuje psa przed pogonią za wiewiórką i zabiciem jej. Zniszczenie i uszkodzenie rzeczy różnią się jedynie ilościowo; jakościowo polegają na spowodowaniu zmian fizycznych w strukturze przedmiotu czynności wykonawczej ${ }^{14}$. Zniszczenie oznacza całkowite unicestwienie lub uszkodzenie rzeczy w takim stopniu, który

11 M. Gałązka, Przestępstwa przeciwko środowisku, s. 921.

12 P. Nalewajko, Przestępstwa przeciwko środowisku, w: Kodeks karny. Część szczególna, t. 1. Komentarz. Art. 117-221, red. M. Królikowski, R. Zawłocki, Warszawa 2013, s. 448.

13 W. Radecki, Przestępstwa przeciwko środowisku, w: Kodeks karny. Część szczególna, t. 1. Komentarz do artykułów 117-221, red. A. Wąsek, R. Zawłocki, Warszawa 2010, s. 754;

J. Sobczak, Przestępstwa przeciwko środowisku, s. 1028.

14 M. Kulik, Przestęstwa przeciwko środowisku, s. 766. 
sprawia, że przestaje ona przynależeć do tego rodzaju, do jakiego należała przed czynem ${ }^{15}$. Zniszczenie ma charter nieodwracalny, ale $\mathrm{w}$ przypadku art. 181 § 2 K.k. nie chodzi o zniszczenie całego ekosystemu ${ }^{16}$. Zniszczenie oznacza spowodowanie śmierci zwierzęcia lub unicestwienie rośliny ${ }^{17}$. Uszkodzenie natomiast polega na naruszeniu substancji rzeczy bez jej unicestwienia $^{18}$. Stanowi naruszenie materii zwierzęcia lub rośliny ${ }^{19}$ bez nieodwracalnego przerwania procesów życiowych ${ }^{20}$. W przypadku zwierzęcia będzie to zatem np. zranienie go, spowodowanie choroby ${ }^{21}$, natomiast w odniesieniu do rośliny jej uszkodzeniem będzie np. złamanie łodygi lub gałęzi, zerwanie kwiatów lub liści czy wykonanie nacięć w korze drzewa, czyli oddziaływanie na roślinę pozbawiające ją walorów estetycznych lub powodujące zmianę jej funkcji ${ }^{22}$.

Przedmiotem czynności wykonawczej są rośliny lub zwierzęta. Trafnie podnosi się $\mathrm{w}$ literaturze, że ochronie na podstawie tego przepisu podlegają także grzyby. Generalnie chodzi tu o wszystkie organizmy żywe ${ }^{23}$ - o rośliny lub zwierzęta w stanie naturalnej swobody, niezależnie od tego, czy występują one w warunkach pierwotnych, naturalnych, czy też zostały zagospodarowane przez człowieka ${ }^{24}$. Nie muszą to być rośliny lub zwierzęta objęte ochroną gatunkową ${ }^{25}$. Ustawodawca używa liczby

15 Tenże, Przestępstwo i wykroczenie uszkodzenia rzeczy, Lublin 2005, s. 63 i n.; M. Dąbrowska-Kardas, P. Kardas, Przestępstwa przeciwko mieniu, w: Kodeks karny. Komentarz, t. 3, red. A. Zoll, Warszawa 2016, s. 370-371; O. Górniok, D. Pleńska, w: System prawa karnego, t. 4. O przestępstwach w szczególności, cz. 2, red. I. Andrejew, L. Kubicki, J. Waszczyński, Wrocław-Warszawa-Kraków-Gdańsk-Łódź 1989, s. 441.

16 J. Sobczak, Przestępstwa przeciwko środowisku, s. 1028.

17 Por. wyrok SN z dnia 24 czerwca 1993 r., III KRN 98/93, OSNKW 1993, z. 9-10, poz. 84; O. Górniok, Przestępstwa przeciwko środowisku, w: tejże i in., Kodeks karny. Komentarz, t. 2. Art. 117-363, Gdańsk 2005, s. 171; M. Kulik, Przestępstwa przeciwko środowisku, s. 483.

18 P. Nalewajko, Przestęstwa przeciwko środowisku, s. 450.

19 M. Kulik, Przestępstwa przeciwko środowisku, s. 483.

20 D. Gruszecka, Przestępstwa przeciwko środowisku, s. 406.

21 M. Gałązka, Przestępstwa przeciwko środowisku, s. 923.

22 J. Sobczak, Przestępstwa przeciwko środowisku, s. 1028; P. Nalewajko, Przestępstwa przeciwko środowisku, s. 450.

23 J. Sobczak, Przestępstwa przeciwko środowisku, s. 1029.

24 D. Gruszecka, Przestęstwa przeciwko środowisku, s. 404; W. Radecki, Przestęsstwa przeciwko środowisku, w: Kodeks karny. Komentarz, red. M. Filar, Warszawa 2016, s. 1117.

${ }^{25}$ Odmiennie, jak się zdaje nietrafnie: J. Lachowski, Przestępstwa przeciwko środowisku, s. 840 . 
mnogiej: „rośliny lub zwierzęta”. Taki sposób redakcji przepisu skłania zwykle przedstawicieli doktryny prawa karnego i orzecznictwa do rozważań, czy do realizacji znamion danego typu czynu zabronionego wystarczy podjęcie zabronionego zachowania wobec jednego egzemplarza przedmiotu czynności wykonawczej. W wielu przypadkach przyjmuje się, że tak jest. Mogłoby się zdawać prima facie, że w omawianym przepisie niezbędne jest powzięcie określonego zachowania w stosunku do kilku egzemplarzy roślin lub zwierząt, ponieważ do znamion tego czynu zabronionego należy spowodowanie istotnej szkody. Jednak w przypadku uszkodzenia, a zwłaszcza zniszczenia rośliny lub zwierzęcia rzadko występującego, będącego na wymarciu etc., zabronione zachowanie sprawcy podjęte wobec jednego tylko egzemplarza może taką właśnie istotną szkodę wyrządzić. Przykładem może być zdarzenie z 2013 r., kiedy pojawiła się $\mathrm{w}$ mediach informacja o turyście, który wyłowił z oceanu ośmiornicę o sześciu mackach, sfotografował ją, a następnie zabił, przyrządził i zjadł. Wkrótce okazało się, że był to okaz niezwykle rzadkiego gatunku ośmiornicy złowiony po raz pierwszy od kilkunastu lat ${ }^{26}$.

Wskazane przez ustawodawcę postępowanie wobec roślin i zwierząt podlega karze ze względu na miejsce popełnienia czynu. Jest nim teren objęty ochroną ${ }^{27}$. Przepis art. 6 pkt 1 ustawy o ochronie przyrody zawiera wyliczenie form ochrony przyrody. Wynika z niego, że do terenów objętych ochroną należą: parki narodowe, rezerwaty przyrody, parki krajobrazowe, obszary chronionego krajobrazu, obszary Natura 2000, pomniki przyrody, stanowiska dokumentacyjne, użytki ekologiczne, zespoły przyrodniczo- krajobrazowe $^{28}$. W parkach narodowych i rezerwatach krajobrazowych zabrania się zachowań mogących umniejszyć walory przyrodnicze tych miejsc. Wykaz zachowań zabronionych zawarty jest w art. 15 ust. 1 ustawy o ochronie przyrody. Natomiast na terenie parku krajobrazowego mogą zostać wprowadzone zakazy uchwałą sejmiku województwa (art. 16 ust. 3). Pełną listę tych zakazów przewiduje art. 17 ust. 1 ustawy o ochronie przyrody. Na obszarze chronionego krajobrazu sejmik województwa w drodze uchwały stanowiącej akt prawa miejscowego wskazuje, które z zakazów

26 M. Budyn-Kulik, Umyślność w prawie karnym i psychologii. Teoria i praktyka sądowa, Warszawa 2015, s. 178.

${ }^{27}$ Szerzej W. Radecki, Przestęstwa przeciwko środowisku, w: Kodeks karny. Komentarz, s. $1120-1121$.

28 Por. szerzej na ten temat J. Sobczak, Przestępstwa przeciwko środowisku, s. 1029-1030. 
wymienionych w art. 24 ust 1a ustawy o ochronie przyrody obowiązują (art. 23a ust. 1 tej ustawy). Obszary Natura 2000 stanowią część lub całość obszarów lub obiektów objętych formami ochrony przyrody z art. 6 ust. 1 ustawy o ochronie przyrody. Związane są ze szczególną ochroną ptaków, siedlisk lub obszarów mających znaczenie dla wspólnoty. W odniesieniu do pomnika przyrody, stanowiska dokumentacyjnego, użytku ekologicznego lub zespołu przyrodniczo-krajobrazowego o tym, które z zakazów wymienionych w art. 45 ust. 1 ustawy o ochronie przyrody obowiązują, decyduje uchwałą rada gminy (art. 44 ust. 1).

Wyliczenie z ustawy o ochronie środowiska powinno być traktowane jako przykładowe, a nie enumeratywne ${ }^{29}$. Terenami chronionymi są również parki kulturowe ${ }^{30}$ oraz uzdrowiska (i obszary ochrony uzdrowiskowej) $)^{31}$. Pogląd ten należy podzielić, z tym jednak zastrzeżeniem, że $\mathrm{w}$ takim przypadku odpowiednie przepisy muszą również przewidywać ochronę przyrody na danym terenie ${ }^{32}$.

Do znamion występku z art. 181 § 2 K.k. należy spowodowanie przez sprawcę istotnej szkody. Jeżeli szkoda taka nie powstanie, czyn sprawcy stanowi występek z art. 127 ustawy o ochronie przyrody ${ }^{33}$. Pojęcie to nie zostało zdefiniowane w Kodeksie karnym. Już samo spowodowanie zniszczeń lub uszkodzeń rośliny albo zwierzęcia ma charakter skutkowy, jednak ustawodawca wymaga ponad to wystąpienia określonego poziomu owego skutku ${ }^{34}$. Istotna szkoda z art. $181 \S 2$ oraz art. $187 \S 1$ K.k. dotyczy świata roślinnego i zwierzęcego. Nie musi mieć charakteru majątkowe$\mathrm{go}^{35}$. Nie można jej utożsamiać ze znaczną szkodą oraz szkodą w wielkich rozmiarach $\mathrm{w}$ rozumieniu art. $115 \S 5,6,7$ K.k. ${ }^{36}$ Chodzi tu raczej wartość

29 Por. W. Radecki, Przestęstwa przeciwko środowisku. Rozdział XXII Kodeksu karnego. Komentarz, Warszawa 2001, s. 74.

30 Art. 16 ustawy z dnia 23 lipca 2003 r. o ochronie zabytków i opiece nad zabytkami, tekst jednolity: Dz. U. z 2020 r. poz. 282 z późn. zm.

31 Art. 33-44 ustawy z dnia 28 lipca 2005 r. o lecznictwie uzdrowiskowym, uzdrowiskach i obszarach ochrony uzdrowiskowej oraz o gminach uzdrowiskowych, tekst jednolity: Dz. U. z 2020 r. poz. 1662 z późn. zm.

32 Zob. D. Gruszecka, Przestępstwa przeciwko środowisku, s. 407.

33 W. Radecki, Przestępstwa przeciwko środowisku, w: Kodeks karny. Komentarz, s. 1121.

34 Nie ma jednak chyba racji J. Lachowski, twierdząc, że suma zniszczeń i uszkodzeń ma wypełniać znamię istotnej szkody (J. Lachowski, Przestępstwa przeciwko środowisku, s. 840). Wystarczy jedno uszkodzenie lub zniszczenie.

35 M. Kulik, Przestępstwa przeciwko środowisku, s. 483.

36 D. Gruszecka, Przestępstwa przeciwko środowisku, s. 407. 
świata przyrodniczego, która często jest wartością niematerialną ${ }^{37}$. Nie da się ocenić istotności szkody in abstracto. Taki sam czyn sprawcy może wyrządzić istotną szkodę na terenie parku narodowego, ale już nie poza nim $^{38}$. Znamię to jest trudne do wykładni, powoduje także określone trudności przy przypisywaniu sprawcy określonej postaci strony podmiotowej $^{39}$. Wydaje się, że znamię istotnej szkody jest w przypadku czynu zabronionego zbędne, ponieważ naruszenie ekosystemu na terenie chronionym niejako ex definitione taką właśnie szkodę powoduje ${ }^{40}$. $\mathrm{O}$ istotności szkody nie decyduje rozległość zniszczeń lub uszkodzeń, o których mowa $\mathrm{w}$ art. 55 ustawy o ochronie przyrody ${ }^{41}$. Nie można jej również utożsamiać wyłącznie z powstaniem zagrożenia dla chronionego gatunk $\mathrm{u}^{42}$.

Występek ten jest powszechny. Popełnić go może każdy; sprawcą może być także właściciel terenu chronionego ${ }^{43}$. W przypadku czynu popełnionego przez zaniechanie odpowiedzialność może ponieść tylko gwarant ${ }^{44}$. Jak wskazuje się w literaturze, obowiązek ten może wynikać z przepisów różnych ustaw, np. z art. 9 ust. 1 ustawy o lasach ciąży na właścicielach lasów ${ }^{45}, \mathrm{z}$ art. 6 ustawy o rybactwie śródlądowym ${ }^{46}$ na uprawnionym do rybactwa w obwodzie rybackim ${ }^{47}$.

Występek z art. 181 § 2 K.k. może być popełniony umyślnie, w obu postaciach zamiaru $^{48}$.W $\S 5$ ustawodawca stworzył nieumyślny odpowiednik

37 P. Nalewajko, Przestępstwa przeciwko środowisku, s. 453; W. Radecki, Przestęsstwa przeciwko środowisku, w: Kodeks karny. Komentarz, s. 1122.

38 W. Radecki, Przestępstwa przeciwko środowisku, w: Kodeks karny. Część szczególna, t. 1, s. 759; P. Nalewajko, Przestęstwa przeciwko środowisku, s. 453.

39 Por. M. Budyn-Kulik, Umyślność..., s. 178.

40 Tamże.

41 Zob. D. Gruszecka, Przestępstwa przeciwko środowisku, s. 408.

42 Zob. J. Lachowski, Przestęstwa przeciwko środowisku, s. 840.

43 J. Sobczak, Przestępstwa przeciwko środowisku, s. 1034; P. Nalewajko, Przestępstwa przeciwko środowisku, s. 448; W. Radecki, Przestępstwa przeciwko środowisku, w: Kodeks karny. Komentarz, s. 1120.

44 D. Gruszecka, Przestępstwa przeciwko środowisku, s. 404; W. Radecki, Przestępstwa przeciwko środowisku, w: Kodeks karny. Część szczególna, t. 1, s. 764-765.

45 Ustawa z dnia 28 września 1991 r., tekst jednolity: Dz. U. z 2020 r. poz. 1463.

46 Ustawa z dnia 18 kwietnia 1985 r., tekst jednolity: Dz. U. z 2019 r. poz. 2168.

47 Zob. W. Radecki, Przestępstwa przeciwko środowisku, w: Kodeks karny. Część szczególna, t. 1, s. 764-765; P. Nalewajko, Przestępstwa przeciwko środowisku, s. 449.

48 M. Kulik, Przestępstwa przeciwko środowisku, s. 448-449; W. Radecki, Przestępstwa przeciwko środowisku, w: Kodeks karny. Część szczególna, t. 1, s. 765; tenże, Przestępstwa przeciwko środowisku, w: System prawa karnego, t. 8. Przestepstwa przeciwko państwu i dobrom 
typu z $\S 2$. Ze względu na to, że do znamion tego czynu zabronionego należy okoliczność modalna miejsca, do przypisania sprawcy odpowiedzialności karnej za jego popełnienie niezbędne jest, by miał on świadomość, że znajduje się na terenie chronionym ${ }^{49}$, że miejsce, $\mathrm{w}$ którym się znajduje, ma szczególny charakter oraz by chciał lub godził się na to, iż jego zachowanie $\mathrm{w}$ tym miejscu podlega karze. Zazwyczaj informacja $\mathrm{w}$ postaci tabliczki ostrzegawczej (informacyjnej) znajduje się w pobliżu chronionego miejsca lub obiektu. Sprawca nie musi znać dokładnie właściwości terenu czy obiektu, ale z racji jego szczególnego statusu musi zdawać sobie sprawę z tego, że istnieją jakieś racje przemawiające za jego szczególną ochroną. Ponieważ ochrona ma związek z przyrodą, istnieje wysokie prawdopodobieństwo, że za jej wprowadzeniem przemawiają właśnie względy przyrodnicze, a zatem wszelkie działanie podejmowane wobec roślin, zwierząt, skał, wody etc. powinno odbywać się z zachowaniem odpowiedniej ostrożności oraz szczególnej dbałości o to, aby nie zaburzyć funkcjonowania ekosystemu ${ }^{50}$. Sprawca powinien przewidywać, że zachowanie podjęte wobec rośliny lub zwierzęcia może spowodować szkodę oraz liczyć się z tym, że może być ona istotna. Jeżeli zatem takie zachowanie podejmuje, pozwala to na przyjęcie założenia, że godzi się na możliwość wyrządzenia takiej szkody. Można mu wówczas przypisać zamiar ewentualny. Dla odpowiedzialności karnej sprawcy nie jest konieczne, aby umiał on sobie wyobrazić rozmiar i wagę szkody ${ }^{51}$. Wystarczy, że uświadamia sobie, iż może wyrządzić poważną, ciężką, nieodwracalną etc. szkodę $\mathrm{w}$ potocznym rozumieniu tych pojęćs ${ }^{52}$. Jeżeli na podstawie oceny całokształtu zachowania sprawcy da się ustalić, że chciał on wyrządzenia istotnej szkody, np. na znak jakiegoś protestu, aby zwrócić uwagę na problemy związane z ekologią, nie ma przeszkód, by w takiej sytuacji przypisać mu zamiar bezpośredni. Ponieważ ustawodawca przewidział typ nieumyślny omawianego występku w art. 181 § 5 K.k., nawet podjęcie

zbiorowym, red. L. Gardocki, Warszawa 2013, s. 471-472; P. Nalewajko, Przestępstwa przeciwko środowisku, s. 455; O. Górniok, Przestępstwa przeciwko środowisku, s. 171; W. Radecki, Przestęstwa przeciwko środowisku, w: Kodeks karny. Komentarz, s. 1122; G. Bogdan, Przestępstwa przeciwko środowisku, s. 550; D. Gruszecka, Przestępstwa przeciwko środowisku, s. 409; M. Gałązka, Przestępstwa przeciwko środowisku, s. 831.

49 M. Budyn-Kulik, Umyślność..., s. 180.

50 Tamże, s. 178-179.

51 Tamże, s. 179.

52 W. Radecki, Przestępstwa i wykroczenia..., s. 261. 
pewnych wysiłków w celu uniknięcia spowodowania istotnej szkody, np. sprawca przed zerwaniem roślinki sprawdza w atlasie, czy jest ona chroniona, albo oblicza, że już wyszedł z terenu chronionego, nie oznacza uniknięcia odpowiedzialności karnej. Do realizacji znamion występku z art. 181 § 5 K.k. wystarczy wymagalność przewidywania przez sprawcę, że może wyrządzić istotną szkodę w świecie przyrodniczym ${ }^{53}$.

\section{Czyn zabroniony $\mathrm{z}$ art. 187 K.k.}

Indywidualnym przedmiotem ochrony przestępstwa z art. 187 K.k. jest wartość przyrodnicza prawnie chronionych terenów i obiektów ${ }^{54}$, do której należy również ich integralnośćc5 oraz walory krajobrazowe ${ }^{56}$. Pogląd, że jest nim świat roślinny i zwierzęcy, należy uznać za zbyt wąski ${ }^{57}$.

Czynność wykonawcza polega na niszczeniu, poważnym uszkodzeniu lub istotnym zmniejszeniu wartości przyrodniczej obiektu lub terenu. Może być zrealizowana zarówno przez działanie, jak i zaniechanie. Ustawodawca niezbyt fortunnie sformułował ten przepis. Prima facie zdawać by się mogło, że wszystkie postaci czynności wykonawczej odnoszą się do wartości terenu lub obiektu. Z językowego punktu widzenia niszczenie lub uszkodzenie wartości nie brzmi dobrze. Przepis ten należy więc odczytywać nieco inaczej: jedynie istotne zmniejszenie odnosi się do wartości terenu lub obiektu. Pojęcie uszkodzenia i zniszczenia należy interpretować podobnie jak na gruncie art. 181 § 2 K.k. Zniszczenie może polegać na wprowadzeniu nieodwracalnych zmian w części lub w całości terenu chronionego albo na całkowitym unicestwieniu obiektu. Poważne uszkodzenie jest znamieniem ocennym ${ }^{58}$. Nie chodzi tu zatem o zachowanie powodujące jakiekolwiek uszkodzenie terenu lub obiektu, lecz

53 M. Budyn-Kulik, Umyślność..., s. 179.

54 M. Kulik, Przestępstwa przeciwko środowisku, s. 494; W. Radecki, Przestępstwa przeciwko środowisku, w: Kodeks karny. Część szczególna, t. 1, s. 811; J. Sobczak, Przestępstwa przeciwko środowisku, s. 1065; P. Nalewajko, Przestęstwa przeciwko środowisku, s. 503; W. Radecki, Przestępstwa przeciwko środowisku, w: Kodeks karny. Komentarz, s. 1151.

55 M. Gałązka, Przestępstwa przeciwko środowisku, s. 934.

56 D. Gruszecka, Przestęstwa przeciwko środowisku, s. 440.

57 Zob. J. Lachowski, Przestępstwa przeciwko środowisku, s. 850.

58 P. Nalewajko, Przestępstwa przeciwko środowisku, s. 504. 
o uszkodzenie o dużej wadze ${ }^{59}$, która może wynikać z rozległości uszkodzenia lub uszkodzenia części terenu czy obiektu, nawet niewielkiej, ale np. trudnej do odtworzenia ${ }^{60}$. Jako przykład podaje się odłamanie gałęzi drzewa stanowiącego pomnik przyrody, uszkodzenie tworów skalnych chronionej jaskini ${ }^{61}$. Ustawodawca chciał w ten sposób „zrównać” ciężar gatunkowy zniszczenia, uszkodzenia oraz zmniejszenia wartości. Zastanawiające jest, że zarówno zwykłe uszkodzenie, o którym mowa w art. 181 $\S 2$ K.k., jak i uszkodzenie poważne z art. 187 § 1 K.k. ma spowodować taki sam skutek - istotną szkodę. Istotne zmniejszenie wartości obiektu także jest znamieniem ocennym. Musi ono polegać na takim zachowaniu, które nie stanowiąc poważnego uszkodzenia, prowadzi do zmniejszenia wartości przyrodniczej terenu lub obiektu ${ }^{62}$.

Wartość przyrodnicza obiektu lub terenu wynika z tych jego cech, z powodu których został on objęty ochroną na podstawie przepisów ustawy o ochronie przyrody ${ }^{63}$. Omawiany przepis penalizuje jedynie istotne (czyli znaczne, poważne) zmniejszenie wartości przyrodniczej ${ }^{64}$. Ustalenie, czy taki skutek nastąpił, zwykle wymagać będzie wiedzy specjalistycznej i powołania biegłego przyrodnika ${ }^{65}$. W literaturze jako przykład realizacji tego znamienia podaje się m.in. wycięcie kosodrzewiny na znacznym obszarze parku narodowego, podtopienie rezerwatu przyrody ${ }^{66}$.

Przedmiotem czynności wykonawczej jest obiekt lub teren prawnie chroniony. Rozgraniczenie między tymi przedmiotami czynności wykonawczej nie wynika wprost z ustawy ${ }^{67}$. Zazwyczaj przyjmuje się, że obiekty prawnie chronione to pomniki przyrody (art. 6 pkt 1, art. 40 ustawy o ochronie przyrody) oraz stanowiska dokumentacyjne (art. 6 pkt 1, art. 41 ustawy o ochronie przyrody) ${ }^{68}$.

59 J. Sobczak, Przestępstwa przeciwko środowisku, s. 1066.

60 M. Gałązka, Przestępstwa przeciwko środowisku, s. 934.

${ }_{61}$ W. Radecki, Przestępstwa przeciwko środowisku, w: Kodeks karny. Komentarz, s. 1154.

62 M. Kulik, Przestęstwa przeciwko środowisku, s. 494.

63 Zob. O. Górniok, Przestępstwa przeciwko środowisku, s. 180.

64 W. Radecki, Przestępstwa i wykroczenia..., s. 261; P. Nalewajko, Przestępstwa przeciwko środowisku, s. 504.

65 J. Sobczak, Przestępstwa przeciwko środowisku, s. 1066.

${ }_{66}$ W. Radecki, Przestępstwa przeciwko środowisku, w: Kodeks karny. Komentarz, s. 1155.

67 P. Nalewajko, Przestępstwa przeciwko środowisku, s. 505-506.

68 M. Kulik, Przestępstwa przeciwko środowisku, s. 494. 
Omawiane przestępstwo ma charakter materialny. Jest znamienne skutkiem $\mathrm{w}$ postaci istotnej szkody ${ }^{69}$. Także w tym przypadku chodzi o szkodę przyrodniczą, a nie matematycznie rozumianą szkodę majątko$w_{a}{ }^{70}$. Trudno tu oczywiście wprowadzić jakieś kryteria szkody istotnej. Będzie to zależało od rodzaju i właściwości owego terenu czy obiektu ${ }^{71}$. Trafnie wskazuje się w literaturze, że ze względu na konstrukcję tego przepisu mamy do czynienia niejako z podwójną istotnością szkody, ponieważ ma ona wynikać z poważnego uszkodzenia lub istotnego zmniejszenia wartości. Nie można jednak tego skutku uznać za uboczny ${ }^{72}$.

Omawiany występek jest również powszechny. Odpowiedzialność karną na podstawie tego przepisu może ponieść także właściciel obiektu lub terenu ${ }^{73}$.

Ustawodawca przewidział umyślny i nieumyślny typ tego przestępstwa. Czyn zabroniony z $\S 1$ popełnić można w obu postaciach zamia$\mathrm{ru}^{74}$. Sprawca musi objąć świadomością w przypadku zniszczenia jedno, przy pozostałych postaciach czynności sprawczej co najmniej dwa znamiona ocenne (spowodowania istotnej szkody oraz odpowiednio - znamię poważnego uszkodzenia lub istotnego zmniejszenia wartości) ${ }^{75}$. Jeżeli sprawca podejmuje zachowania, których niszczycielski charakter nie ulega wątpliwości, popełnia czyn umyślnie, gdy chce jego nastąpienia w zamiarze bezpośrednim; gdy godzi się na spowodowanie istotnej szkody - w zamiarze ewentualnym. Natomiast gdy sądzi, że tego uniknie, popełnia czyn nieumyślnie w postaci świadomej nieumyślności; wtedy w grę może wchodzić odpowiedzialność z art. 187 § 2 K.k., przewidującego typ

69 J. Sobczak, Przestęstwa przeciwko środowisku, s. 1066.

70 M. Kulik, Przestęstwa przeciwko środowisku, s. 494.

71 M. Budyn-Kulik, Umyślność..., s. 180.

72 W. Radecki, Przestępstwa przeciwko środowisku, w: Kodeks karny. Komentarz, s. 1155.

73 J. Sobczak, Przestępstwa przeciwko środowisku, s. 1067; P. Nalewajko, Przestępstwa przeciwko środowisku, s. 503.

${ }_{74}$ M. Kulik, Przestępstwa przeciwko środowisku, s. 458; J. Sobczak, Przestępstwa przeciwko środowisku, s. 1067; W. Radecki, Przestępstwa przeciwko środowisku, w: Kodeks karny. Część szczególna, t. 1, s. 817; tenże, Przestępstwa przeciwko środowisku, w: System prawa karnego, t. 8, s. 470-471; P. Nalewajko, Przestępstwa przeciwko środowisku, s. 506; O. Górniok, Przestępstwa przeciwko środowisku, s. 180; G. Bogdan, Przestępstwa przeciwko środowisku, s. 574; D. Gruszecka, Przestępstwa przeciwko środowisku, s. 442; A. Marek, Kodeks karny. Komentarz, Warszawa 2010, s. 432.

${ }^{75}$ M. Budyn-Kulik, Umyślność..., s. 180. 
nieumyślny ${ }^{76}$. W sytuacji gdy sprawca nie uświadamiał sobie charakteru terenu lub obiektu i/lub możliwości spowodowania skutku w postaci istotnej szkody, chociaż powinien i mógł to przewidzieć, można mu przypisać nieświadomą nieumyślność (art. 187 § 2 K.k.).

Nieco bardziej skomplikowane jest przypisanie strony podmiotowej $\mathrm{w}$ przypadku znamienia istotnego zmniejszenia wartości przyrodniczej terenu lub obiektu. Ma ono charakter ocenny. Do dokonania prawidłowej oceny wartości przyrodniczej terenu lub obiektu potrzebna jest pewna wiedza na temat specyfiki danego obiektu lub terenu, a nierzadko także specjalistyczna wiedza przyrodnicza. Z perspektywy strony podmiotowej znamię to "zlewa się" niejako ze znamieniem istotnej szkody. Bardziej złożona staje się sytuacja wówczas, gdy sprawca nie uświadamia sobie, że teren czy obiekt podlega ochronie. Pojawia się wtedy problem, czy można od sprawcy wymagać, by zdawał sobie sprawę, że teren lub obiekt jest chroniony. Jeżeli stanowi on typowy przykład obiektu lub terenu, który zwykle korzysta z ochrony, można od sprawcy wymagać powinności szczególnie ostrożnego zachowania podczas przebywania na takim terenie lub w pobliżu obiektu. Będzie mu można wówczas przypisać odpowiedzialność za popełnienie czynu zabronionego nieumyślnie. W sytuacji gdy obiekt lub teren nie są typowo chronione, a informacja o tym, że dany obiekt czy teren takiej ochronie podlega, nie była dostępna dla sprawcy, nie można od niego wymagać, by uświadamiał sobie możliwość realizacji znamion omawianego czynu zabronionego nawet nieumyślnie ${ }^{77}$.

„Istotne zmniejszenie wartości przyrodniczej” prawnie chronionego terenu jest znamieniem czynu zabronionego z art. 187 \& 1 K.k. Czyn ten może zostać popełniony $\mathrm{w}$ obu postaciach zamiaru ${ }^{78}$. W literaturze omawiane znamię wykłada się jako zmniejszenie wartości ${ }^{79}$ lub zakłócenie funkcjonowania danego terenu prowadzące do jego degeneracji ${ }^{80}$. Trafnie podkreśla się niedookreśloność tego znamienia, wskazując, że dla

76 Tamże, s. 181.

77 Tamże.

78 M. Kulik, Przestępstwa przeciwko środowisku, s. 458; P. Nalewajko, Przestępstwa przeciwko środowisku, s. 506; W. Radecki, Przestępstwa przeciwko środowisku, s. 938; tenże, Przestępstwa przeciwko środowisku, w: Kodeks karny. Część szczególna, t. 1, s. 817; O. Górniok, Przestępstwa przeciwko środowisku, s. 180; G. Bogdan, Przestępstwa przeciwko środowisku, s. 574; D. Gruszecka, Przestępstwa przeciwko środowisku, s. 442.

79 M. Kulik, Przestęstwa przeciwko środowisku, s. 458.

80 P. Nalewajko, Przestępstwa przeciwko środowisku, s. 504. 
właściwej oceny skutku może być niezbędne zasięgnięcie opinii biegłego przyrodnika ${ }^{81}$. Z racji tego, że czyn może być popełniony tylko w określonym miejscu, sprawca ma zwykle świadomość, że przyroda jest w tym miejscu pod szczególną ochroną. Można zatem przyjąć, iż dorosły, poczytalny sprawca przypuszcza, że jakakolwiek ingerencja $\mathrm{w}$ przyrodę $\mathrm{w}$ takim miejscu lub obiekcie może spowodować istotne zmniejszenie jej wartości; zwłaszcza wówczas, gdy nie jest specjalistą i nie potrafi na przykład odróżnić roślin chronionych od innych. Jeżeli kontynuuje zamierzone zachowanie mimo tego, akceptuje taką możliwość. W przypadku jednak gdy z jakichś przyczyn sprawca nie ma świadomości, że jest na terenie chronionym (chociaż mógł ją uzyskać) i w związku z tym, że może spowodować owo zmniejszenie jego wartości przyrodniczej, ustawodawca w $\S 2$ przewidział typ nieumyślny.

\section{Czyn zabroniony z art. 188 K.k.}

Indywidualnym przedmiotem ochrony przestępstwa z art. 188 K.k. jest wartość przyrodnicza i krajobrazowa określonego terenu ${ }^{82}$. Zbyt wąskie jest przyjęcie, że jest nim świat roślinny i zwierzęcy ${ }^{83}$.

Czynność wykonawcza polega na wznoszeniu obiektów budowlanych lub powiększaniu obiektów już istniejących, lub na prowadzeniu działalności gospodarczej. Pojęcie obiektu budowlanego zostało zdefiniowane $w$ art. 3 pkt 1 ustawy Prawo budowlane ${ }^{84}$. Jest to budynek, budowla bądź obiekt małej architektury (niewielkie obiekty, np. kapliczki, wodotryski, piaskownice, huśtawki, śmietniki - art. 3 pkt 4) wraz z instalacjami zapewniającymi możliwość użytkowania obiektu zgodnie z jego przeznaczeniem, wzniesiony z użyciem wyrobów budowlanych. Przepis art. 76 ust. 1 ustawy Prawo ochrony środowiska stanowi, że żaden nowo zbudowany lub zmodernizowany obiekt budowlany nie może być oddany

81 W. Radecki, Przestępstwa przeciwko środowisku, w: Kodeks karny. Część szczególna, t. 1, s. $815-816$.

82 Tamże, s. 821; M. Kulik, Przestępstwa przeciwko środowisku, s. 495; J. Sobczak, Przestępstwa przeciwko środowisku, s. 1068; P. Nalewajko, Przestępstwa przeciwko środowisku, s. 509; W. Radecki, Przestępstwa przeciwko środowisku, w: Kodeks karny. Komentarz, s. 1156.

83 Zob. J. Lachowski, Przestęstwa przeciwko środowisku, s. 853.

84 Ustawa z dnia 7 lipca 1994 r., tekst jednolity: Dz. U. z 2020 r. poz. 1333 z późn. zm. 
do użytkowania, jeżeli nie spełnia wymagań ochrony środowiska, w tym zastosowania odpowiednich środków technicznych służących ochronie środowiska (art. 76 pkt 2). Ustawodawca w omawianym przepisie zabrania zarówno wznoszenia nowego obiektu, jak i rozbudowy istniejącego przez powiększenie jego kubatury (i/lub powierzchni) ${ }^{85}$.

$\mathrm{W}$ art. 188 K.k. kryminalizowane jest wznoszenie lub powiększanie obiektu wbrew przepisom. Chodzi tu przede wszystkim o przepisy ustawy o ochronie przyrody oraz ustawy Prawo ochrony środowiska ${ }^{86}$. Z treści art. 15 ust. 1 pkt 1 ustawy o ochronie przyrody wynika, że w parkach narodowych oraz $\mathrm{w}$ rezerwatach przyrody zabrania się budowy lub przebudowy obiektów budowlanych i urządzeń technicznych, z wyjątkiem obiektów i urządzeń służących celom parku narodowego albo rezerwatu przyrody. Natomiast przepis art. 73 ust. 1 pkt 1 ustawy Prawo ochrony środowiska stanowi, że w miejscowym planie zagospodarowania przestrzennego oraz $\mathrm{w}$ decyzji o warunkach zabudowy i zagospodarowania terenu uwzględnia się w szczególności ograniczenia wynikające m.in. $\mathrm{z}$ ustanowienia $\mathrm{w}$ trybie ustawy o ochronie przyrody parku narodowego, rezerwatu przyrody, parku krajobrazowego, obszaru chronionego krajobrazu, obszaru Natura 2000, zespołu przyrodniczo-krajobrazowego, użytku ekologicznego, stanowiska dokumentacyjnego, pomników przyrody oraz ich otulin ${ }^{87}$.

Pojęcie działalności gospodarczej definiuje art. 3 ustawy Prawo przedsiębiorców ${ }^{88}$. Działalność gospodarcza spełniająca znamiona określone $\mathrm{w}$ komentowanym przepisie nie musi być działalnością prowadzoną wbrew przepisom. Chodzi tu o działalność potencjalnie zagrażającą środowisku ${ }^{89}$. Przykładem takiej działalności gospodarczej jest działalność polegająca na zanieczyszczeniu wody, powietrza, powodowaniu hałasu lub wibracji, niezależnie od stopnia generowania tych zjawisk ${ }^{90}$.

85 P. Nalewajko, Przestępstwa przeciwko środowisku, s. 510.

86 Por. szerzej D. Gruszecka, Przestępstwa przeciwko środowisku, s. 444-445.

87 Nie ma miejsca w tym opracowaniu na szczegółowe omówienie tej kwestii, ale w przypadku otulin jest to rzecz nieco bardziej skomplikowana. Por. W. Radecki, Przestępstwa przeciwko środowisku, w: Kodeks karny. Komentarz, s. 1157.

88 Ustawa z dnia 6 marca 2018 r., tekst jednolity: Dz. U. z 2018 r. poz. 646 z późn. zm.

89 D. Gruszecka, Przestęstwa przeciwko środowisku, s. 444; M. Kulik, Przestępstwa przeciwko środowisku, s. 495.

90 J. Sobczak, Przestępstwa przeciwko środowisku, s. 1070; G. Bogdan, Przestępstwa przeciwko środowisku, s. 576; P. Nalewajko, Przestępstwa przeciwko środowisku, s. 511. 
Do znamion czynu zabronionego z art. 188 K.k. należy popełnienie czynu na terenie objętym ochroną lub w jego otulinie. Otuliną terenu objętego ochroną jest strefa ochronna granicząca $z$ formą ochrony przyrody i wyznaczona indywidualnie dla formy ochrony przyrody w celu zabezpieczenia przed zagrożeniami zewnętrznymi wynikającymi z działalności człowieka (art. 4 pkt 14 ustawy o ochronie przyrody). Otulinę wyznacza się na obszarach graniczących z parkiem narodowym (art. 11 pkt 1), można ją również wyznaczyć na obszarach graniczących z rezerwatem (art. 13 pkt 2) oraz z parkiem krajobrazowym (art. 16 pkt 2 ustawy o ochronie przyrody).

Przestępstwo z art. 188 K.k. ma charakter formalny ${ }^{91}$. Jego dokonanie nie zależy od wystąpienia jakiegokolwiek skutku. Za nietrafny należy uznać pogląd odmienny, jakoby skutkiem było wzniesienie lub rozbudowa obiektu oraz sprowadzenie realnego, acz niebezpośredniego niebezpieczeństwa dla środowiska ${ }^{92}$.

Jest to przestępstwo powszechne. Zdaniem J. Sobczaka jego sprawcą nie może być urzędnik, który wydał wbrew przepisom pozwolenie budowlane ${ }^{93}$. W zależności jednak od konkretnego stanu faktycznego może on ponieść odpowiedzialność nie tylko z art. 231 K.k., ale również za pomocnictwo do czynu z art. 188 K.k., nie da się wykluczyć pojęciowo także współsprawstwa. Ze względu na charakter czynu (prowadzenie budowy, działalności gospodarczej) należy rozważyć możliwość poniesienia odpowiedzialności przez podmiot zbiorowy ${ }^{94}$.

Stroną podmiotową jest umyślność, w obu postaciach zamiaru ${ }^{95}$. Ze zrozumiałych względów ustawodawca zrezygnował tu z wprowadzenia typu nieumyślnego.

91 J. Sobczak, Przestępstwa przeciwko środowisku, s. 1069; M. Gałązka, Przestępstwa przeciwko środowisku, s. 935; M. Kulik, Przestępstwa przeciwko środowisku, s. 494; A. Marek, Kodeks karny..., s. 433; P. Nalewajko, Przestępstwa przeciwko środowisku, s. 511; W. Radecki, Przestęsstwa przeciwko środowisku, w: Kodeks karny. Komentarz, s. 1157.

92 Zob. J. Lachowski, Przestępstwa przeciwko środowisku, s. 854.

93 J. Sobczak, Przestępstwa przeciwko środowisku, s. 1070.

94 D. Gruszecka, Przestęstwa przeciwko środowisku, s. 444.

95 J. Sobczak, Przestępstwa przeciwko środowisku, s. 1070; M. Gałązka, Przestępstwa przeciwko środowisku, s. 935; P. Nalewajko, Przestępstwa przeciwko środowisku, s. 512. 


\section{Ustawowy i sądowy wymiar kary}

Wszystkie omawiane przestępstwa stanowią występki zagrożone karami: grzywny, ograniczenia wolności lub pozbawienia wolności do lat 2 (art. 181 § 2, art. 187 § 1, art. 188 K.k.); grzywny lub ograniczenia wolności (art. 181 § 5, art. 187 § 2 K.k.).

W przypadku skazania za którekolwiek z omawianych przestępstw, ze względu na zagrożenie karą, nie jest możliwe orzeczenie wobec sprawcy środka karnego w postaci pozbawienia praw publicznych. Sąd może orzec zakaz zajmowania określonego stanowiska albo wykonywania określonego zawodu $\mathrm{z}$ art. 41 § 1 K.k. Jeżeli sprawca popełnił jedno z omawianych przestępstw w związku z prowadzeniem działalności gospodarczej, możliwe jest również orzeczenie środka w postaci zakazu prowadzenia takiej działalności, jeżeli dalsze jej prowadzenie zagraża istotnym dobrom chronionym prawem (art. $41 \S 2$ K.k.). Zakazy te mogą być orzeczone na okres od roku do lat 10. Możliwe jest podanie wyroku do publicznej wiadomości, w określony sposób, jeżeli sąd uzna to za celowe, w szczególności ze względu na społeczne oddziaływanie skazania (art. 43b K.k.). Jeżeli sprawca użył jakichś narzędzi, przyrządów etc. do popełnienia czynu, sąd może orzec ich przepadek (art. 44 § 2 K.k.) lub, gdy nie jest to możliwe, przepadek ich równowartości (art. 44 § 4 K.k.).

\section{Zbieg przepisów ustawy}

Czyn zabroniony z art. 181 § 2 lub 5 K.k. może jednocześnie realizować znamiona czynów stypizowanych $w$ innych przepisach tworzących typy przestępstw i wykroczeń. Co do zasady art. 181 K.k. wyłącza ich stosowanie na zasadzie specjalności lub konsumpcji ${ }^{96}$. Czyn sprawcy wypełniający znamiona występku z art. 181 K.k. stanowi jednocześnie przestępstwo z art. 288 K.k. Między tymi przepisami zachodzi zbieg rzeczywisty właściwy, skutkujący kumulatywną kwalifikacją ${ }^{97}$. Podobna relacja zachodzi

\footnotetext{
96 M. Kulik, Przestępstwa przeciwko środowisku, s. 484.

97 Odmiennie J. Lachowski, zdaniem którego art. 181 K.k. stanowi lex specialis. Zob. tegoż, Przestępstwa przeciwko środowisku, s. 838.
} 
między przepisem art. 181 i art. 290 K.k. (wyrąb drzewa w lesie) $)^{98}$ oraz art. 181 § 3 K.k. ${ }^{99}$

Także w odniesieniu do czynu zabronionego z art. 187 § 1 K.k. możliwy jest zbieg rzeczywisty właściwy przepisów z art. 288 K.k. ${ }^{100} \mathrm{~W}$ przypadku gdy skutkiem zniszczenia lub uszkodzenia obiektu był pożar, mamy do czynienia ze zbiegiem rzeczywistym właściwym przepisu art. $187 \mathrm{i}$ art. 163 $\S 1$ lub 2 K.k. ${ }^{101}$

\section{Zakończenie}

Ochrona przyrody jest zapewniana przede wszystkim przez przepisy należące do szeroko rozumianego prawa administracyjnego. Prawo karne ma charakter ultima ratio - jego ingerencja w tę materię jest czymś w pewnym sensie wyjątkowym. Wkracza w ostateczności, aby zagwarantować przestrzeganie norm przewidzianych $\mathrm{w}$ przepisach należących do innych gałęzi prawa. Rodzi to określone problemy, wynikające z konieczności odwoływania się do regulacji istniejących w ramach innych gałęzi prawa, posługujących się swoistą terminologią. Umieszczenie przestępstw przeciwko różnym dobrom w jednym akcie prawnym (Kodeksie karnym) ma swoje zalety, nie jest jednak pozbawione także pewnych wad. Ze względu na rosnącą potrzebę ochrony środowiska, a jednocześnie specyfikę i złożoność tej materii być może lepszym rozwiązaniem byłoby przeniesienie przestępstw (oraz wykroczeń, obecnie znajdujących się w Kodeksie wykroczeń) do aktu prawnego kompleksowo regulującego kwestie związane z ochroną środowiska.

98 W. Radecki, Przestępstwa przeciwko środowisku, w: Kodeks karny. Część szczególna, t. 1, s. 619; A. Marek, Kodeks karny..., s. 428.

99 W. Radecki, Przestępstwa przeciwko środowisku, w: Kodeks karny. Komentarz, s. 1123.

100 Tenże, Przestępstwa przeciwko środowisku, w: Kodeks karny. Część szczególna, t. 1, s. 818. Podobnie M. Kulik, Przestępstwo i wykroczenie..., s. 221 i n.

${ }^{101}$ W. Radecki, Przestępstwa przeciwko środowisku, w: Kodeks karny. Część szczególna, t. 1, s. 818 . 


\section{Bibliografia}

Budyn-Kulik M., Umyślność w prawie karnym i psychologii. Teoria i praktyka sądowa, Warszawa 2015.

Górniok O., Hoc S., Kalitowski M., Przyjemski S.M., Sienkiewicz Z., Szumski J., Tyszkiewicz L., Wąsek A., Kodeks karny. Komentarz, t. 2. Art. 117-363, Gdańsk 2005.

Kodeks karny. Część szczególna, t. 1. Komentarz. Art. 117-221, red. M. Królikowski, R. Zawłocki, Warszawa 2013.

Kodeks karny. Część szczególna, t. 1. Komentarz do artykułów 117-221, red. A. Wąsek, R. Zawłocki, Warszawa 2010.

Kodeks karny. Komentarz. Część szczególna, red. J. Giezek, Warszawa 2014.

Kodeks karny. Komentarz. Część szczególna, t. 2, red. A. Zoll, Warszawa 2008.

Kodeks karny. Komentarz. Część szczególna, t. 3, red. A. Zoll, Warszawa 2016.

Kodeks karny. Komentarz, red. A. Grześkowiak, K. Wiak, Warszawa 2015.

Kodeks karny. Komentarz, red. M. Filar, Warszawa 2016.

Kodeks karny. Komentarz, red. M. Mozgawa, Warszawa 2015.

Kodeks karny. Komentarz, red. R.A. Stefański, Warszawa 2015.

Kodeks karny. Komentarz, red. V. Konarska-Wrzosek, Warszawa 2016.

Kulik M., Przestępstwo i wykroczenie uszkodzenia rzeczy, Lublin 2005.

Marek A., Kodeks karny. Komentarz, Warszawa 2010.

Radecki W., Przestępstwa przeciwko środowisku. Rozdział XXII Kodeksu karnego. Komentarz, Warszawa 2001.

System prawa karnego, t. 4. O przestępstwach w szczególności, cz. 2, red. I. Andrejew,

L. Kubicki, J. Waszczyński, Wrocław-Warszaw-Gdańsk-Łódź 1989.

System prawa karnego, t. 8. Przestępstwa przeciwko państwu i dobrom zbiorowym, red. L. Gardocki, Warszawa 2013.

\section{Streszczenie}

Ochrona przyrody to przede wszystkim domena prawa administracyjnego, jednak prawnokarna ochrona środowiska stanowi znaczące uzupełnienie regulacji mających na celu utrzymanie równowagi przyrodniczej oraz dążenie do zachowania możliwości odnawiania zasobów naturalnych. W polskim Kodeksie karnym $\mathrm{w}$ rozdziale poświęconym przestępstwom przeciwko środowisku zawartych jest pięć samoistnych typów przestępstw, do znamion których należy szczególne miejsce ich popełnienia w postaci terenu lub obiektu objętego ochroną. Są to przestępstwa stypizowane w art. 181 \& 2 i 5, art. 187 oraz art. 188 K.k. We wszystkich przedmiotem ochrony jest środowisko. Ich pozostałe znamiona są 
zróżnicowane. Ponieważ omawiane przepisy mają charakter akcesoryjny, przy ich wykładni konieczne jest odwołanie się do innych niż Kodeks karny ustaw, co rodzi określone problemy. Mogą one pozostawać w różnych konfiguracjach zbiegu z innymi przepisami.

Słowa kluczowe: prawo karne, ochrona środowiska

\section{THE CRIMINAL LAW PROTECTION OF OBJECTS AND PROTECTED AREAS ACCORDING TO CHOSEN REGULATIONS OF CHAPTER XXII OF THE CRIMINAL CODE (ART. 181 § 2 AND 5, ART. 187, ART. 188 C.C.) \\ Sum mary}

The aim of environmental protection in criminal law is to maintain sustainability in nature as well as try to protect the renewability of natural resources. The Polish Criminal Code contains five autonomic types of crime, which are characterized, among others, by the specific crime scene, such as 'an environmentally protected area or object'. They are included in the Chapter of Crimes against the Environment. They realize the so-called traditional protection of nature, conservational in character. These types are mentioned in: art. $181 \S 2$ and 5 C.C., art. 187 C.C. and art. 188 C.C. They are accessory to other regulations beyond Criminal Code.

Key words: criminal law, environment protection

\section{УГОЛОВНО-ПРАВОВАЯ ЗАЩИТА ОХРАНЯЕМЫХ ОБЪЕКТОВ И ТЕРРИТОРИЙ В КОНТЕКСТЕ ОТДЕЛЬНЫХ ПОЛОЖЕНИЙ ГЛАВЫ XXII УГОЛОВНОГО КОДЕКСА (СТ. 181 § 2 И 5, СТ. 187, СТ. 188 УК)}

\section{Резюме}

Охрана окружающей среды - это, прежде всего, область административного права, однако защита окружающей среды в соответствии с уголовным законодательством является важным дополнением к нормативным актам, направленным на поддержание экологического баланса и стремление поддерживать возможность возобновления природных ресурсов. В Уголовном кодексе Республики Польша, в главе, посвященной экологическим преступлениям, выделяются пять самостоятельных видов преступлений, признаками состава которых является конкретное место, где они были совершены, в виде охраняемой территории или объекта. Это преступления, предусмотренные ст. 181 § 2 и 5, ст. 187 и ст. 188 Уголовного кодекса. Во всех них 
предметом защиты является окружающая среда. Другие признаки состава этих преступлений разнообразны. Поскольку рассматриваемые положения акцессорного характера, при их толковании необходимо обращаться к другим законам, помимо Уголовного кодекса, что создает определенные проблемы. Они могут различным обозом пересекаться с другими нормативными актами.

Ключевые слова: уголовное право, охрана окружающей среды 